\title{
Work-Life Balance Karyawan Milenial Level Manajerial Bank Tabungan Negara Syariah
}

\author{
Gineung Raditya Dennira dan Dian Ekowati \\ Universitas Airlangga \\ Email: gineung.raditya.dennira-2017@feb.unair.ac.id dan d.ekowati@feb.unair.ac.id \\ Diterima: April 2020 ; Dipublikasikan Juli 2020
}

\begin{abstract}
ABSTRAK
Saat ini partisipasi generasi milenial dalam angkatan kerja mulai mendominasi. Namun para milenial yang bekerja menghadapi kondisi yang sulit dalam menghadapi stres dan kelelahan bekerja. Generasi milenial lebih menginginkan adanya work-life balance dibandingkan generasi Xers dan Baby Boomers. Work-life balance telah menjadi perhatian bagi karyawan yang menuntut pada keseimbangan kualitas kehidupan kerja dengan kualitas kehidupan pribadi. Studi penelitian ini dilakukan dengan metode kualitatif menggunakan pendekatan fenomenologi yang sesuai dengan tujuan penelitian yaitu mengeksplorasi secara mendalam tentang work-life balance. Data dikumpulkan dari wawancara dengan sejumlah 10 karyawan milenial level manajerial di lingkungan kerja berbasis syariah yang terindikasi merasakan hambatan dalam usahanya mencapai work-life balance. Temuan dari penelitian ini berhasil mengidentifikasi penyebab, konflik peran, dampak work-life balance, upaya individu mengelola work-life balance, faktor yang mendasari pemaknaan konsep work-life balance, dan manifestasi pemaknaan work-life balance. Hambatan yang ditemui individu dalam memenuhi work-life balance disebabkan oleh keterbatasan diri dalam mendistribusikan personal resources terhadap domain kehidupan. Pemaknaan konsep work-life balance oleh karyawan milenial level manajerial didasari oleh faktor individual dan faktor organisasi. Manifestasi pemaknaan setiap individu dilakukan dengan cara yang unik dan berbeda yang mencakup keadilan pembagian resources, perolehan kualitas hidup, hubungan timbal balik antar domain, pemisahan domain secara jelas, kesetaraan kehidupan duniawi dan akhirat.
\end{abstract}

Kata Kunci : work-life balance, fenomenologi, milenial, level manajerial, syariah

\section{ABSTRACT}

At present the participation of millennials in the workforce begins to dominate. However, millennials who work face difficult conditions in dealing with stress and work fatigue. Millennials want more work-life balance than Xers and Baby Boomers generations. Work-life balance has become a concern for employees who demand the balance of work life quality dan personal life quality. This research using a phenomenological approach with a qualitative method that is in accordance with the research objectives, namely exploring in depth about work-life balance. The data was collected from interviews with 10 managerial-level millennial employees in a sharia-based work environment indicated to feel obstacles in their efforts to achieve work-life balance. The findings of this research successfully identified the causes, role conflicts, the impact of work-life balance, individual efforts to manage work-life balance, the factors underlying the meaning of the concept of work-life balance, and the manifestations of the meaning of work-life balance. The obstacles encountered by individuals in fulfilling work-life balance are caused by self-limitations in distributing personal resources to the life domain. The meaning concept of work-life balance by millennial on managerial level employees is based on individual factors and organizational factors. Manifestation of the meaning on each individual is carried out in a unique and different way that includes the fairness on resources distribution, the acquisition of life quality, mutual relations interdomains, clear domain separation, equality of worldly life and afterlife.

Keywords : work-life balance, phenomenological, millennials, managerial level, sharia

\section{PENDAHULUAN}

Saat ini partisipasi generasi milenial dalam angkatan kerja mulai mendominasi. Generasi Y atau yang biasa disebut dengan generasi milenial merupakan generasi yang lahir antara tahun 1980 sampai 1995 (Buzza, 2017). Sedangkan menurut Levenson (2010), generasi milenial lahir antara tahun 1980 sampai dengan akhir tahun 1990-an. Generasi milenial merupakan generasi yang mendominasi angkatan kerja pada tahun 2017 yang menunjukkan prosentase $35 \%$ berdasarkan Pew Research Center, dimana angkatan kerja dari generasi Xers sebesar 33\%, generasi Baby Boomers sebesar $25 \%$, generasi $Z$ sebesar $5 \%$. 
Berdasarkan hasil Survei Angkatan Kerja Nasional pada tahun 2017, generasi milenial di Indonesia yang menduduki posisi manajer menunjukkan prosentase sebesar 1,37\%. Sementara itu, prosentase dalam posisi manajer diduduki oleh generasi $\mathrm{X}$ sebesar $2,71 \%$ dan generasi baby boomer sebesar $1,79 \%$. Prosentase posisi manajer yang diduduki oleh generasi milenial dapat meningkat karena seiring berjalannya waktu terdapat perubahan struktur kependudukan yang memungkinkan adanya bonus demografi, dimana pada tahun 2017 penduduk Indonesia telah didominasi oleh generasi milenial sebesar 33,75\% dengan jumlah yang hampir berimbang antara pria dan wanita (Yembise, 2018). Namun, para milenial yang bekerja menghadapi kondisi yang sulit dalam menghadapi stres dan kelelahan bekerja (Smith, 2018). Menurut The American Institution of Stress pada tahun 2017, terdapat $80 \%$ karyawan milenial merasa stres terkait pekerjaan dan sebesar 29\% karyawan milenial merasa kelelahan setelah bekerja. Tingkat stres kerja yang lebih tinggi telah dirasakan oleh karyawan pria dan wanita berusia muda level manajer yang bekerja lembur berlebihan (Krantz et al., 2005). Stres kerja merupakan masalah sosial yang serius dihadapi oleh generasi milenial saat ini (Smith, 2018).

Generasi milenial lebih menginginkan adanya work-life balance dibandingkan generasi Xers dan Baby Boomers (Sonier, 2012). Generasi milenial lebih tertarik dengan work-life balance daripada sekedar berorientasi pada uang (Buzza, 2017). Keluarga, teman, dan gaya hidup adalah prioritas dari generasi milenial (Safer, 2008). Fenomena ini terjadi karena generasi milenial menghabiskan lebih banyak waktu bersama keluarga maupun teman - teman mereka dan memiliki kepentingan pribadi di luar tempat kerja untuk bersosialisasi dan menyalurkan hobi. Hal ini berbeda dengan generasi Xers dan Baby Boomers, dimana mereka adalah pecandu kerja yang memiliki sedikit angan tentang work-life balance (Myers dan Sadaghiani, 2010). Work-life balance tidak lagi hanya menjadi fenomena budaya barat, namun mulai menjadi fenomena budaya timur yang disebabkan oleh globalisasi yang mempengaruhi organisasi di seluruh dunia (Lewis et al., 2007). Menurut Lockwood (2003), work-life balance adalah suatu keadaan yang seimbang pada dua tuntutan atau lebih, dimana pekerjaan dan kehidupan seorang individu adalah setara. Pandangan lain tentang kehidupan yang seimbang adalah pemenuhan kepuasan pada semua domain kehidupan dan untuk melakukannya dibutuhkan sumber daya pribadi seperti energi, waktu, perhatian, dan komitmen yang disalurkan dengan baik di seluruh domain (Kirchmeyer, 2000).

Work-life balance menjadi sebuah kebijakan dan program yang dapat ditawarkan organisasi kepada karyawan untuk mengurangi tekanan dan konflik multi peran ketika menyeimbangkan antara karir dan keluarga (Jang et al., 2011). Dengan membantu karyawan mencapai work-life balance, maka akan berpengaruh pada organisasi karena dapat meningkatkan kesehatan mental maupun kepuasan kerja karyawan (Jang et al., 2011). Oleh karena itu, work-life balance telah menjadi isu penting di lingkungan kerja dan lingkungan sosial saat ini karena kehidupan pribadi dan pekerjaan merupakan dua domain yang memicu imbalance (Greenhaus, 2003), dimana karyawan level manajerial merasa sulit untuk menggabungkan kehidupan pribadi dan kehidupan profesional pekerjaan mereka yang terpenuhi dan terpuaskan dengan baik (Auster, 2001; Chalofsky, 2003). Tantangan untuk menyeimbangkan waktu antara pekerjaan dan kehidupan pribadi merupakan hal yang harus dihadapi oleh sebagian besar karyawan yang bekerja di organisasi yang berfokus pada bisnis, termasuk perusahaan di bidang perbankan. Bank Tabungan Negara Syariah merupakan Unit Usaha Syariah (UUS) yang berada di bawah naungan manajemen dari PT. Bank Tabungan Negara (Persero) Tbk yang merupakan salah satu Badan Usaha Milik Negara (BUMN) terkemuka di Indonesia. BTN Syariah merupakan bank yang operasionalnya menggunakan prinsip - prinsip syariah di dalam Islam.

Penggunaan prinsip syariah yang berdasarkan hukum Islam merupakan bagian dari Islam sebagai agama (Abubakar, 2017). Tujuan umum dari hukum Islam adalah untuk kesejahteraan umat manusia. Tujuan secara khususnya dikenal sebagai maqasid al-Shariah yang bertujuan untuk memastikan keseimbangan, perlindungan agama, dan kehidupan (Ahmed, 2006). Berdasarkan penjelasan tersebut, maka seorang individu yang bekerja di lingkungan kerja syariah termasuk Bank Tabungan Negara Syariah, merupakan salah satu bentuk upaya dalam melaksanakan kewajibannya sebagai umat muslim dalam memenuhi kesejahteraan kehidupannya baik dari segi materi maupun psikologis. 
Menurut Laporan Keberlanjutan BTN (2017), disampaikan bahwa proporsi karyawan yang menduduki jabatan manajerial dan tergolong sebagai kaum milenial $(\leq 30$ Tahun) semakin meningkat dari tahun 2015 hingga 2017. Pada tahun 2015, sebesar 12,89\% jabatan manajerial diduduki oleh generasi milenial. Pada tahun 2016 menunjukkan prosentase sebesar 15\%, sedangkan pada tahun 2017 menunjukkan prosentasi sebesar 26,42\% jabatan manajerial diduduki oleh kaum milenial. Karyawan yang menduduki posisi manajerial memiliki tanggung jawab yang lebih besar dengan beban target yang harus tercapai. Dengan tanggung jawab manajerial yang harus diemban, tentu akan menambah beban kerja para karyawan, khususnya karyawan milenial level manajerial (Smith, 2018). Hasil pra-penelitian yang dilakukan peneliti dengan melakukan wawancara terhadap lima orang karyawan milenial level manajerial di PT. Bank Tabungan Negara (Persero) Tbk: Kantor Cabang Syariah Surabaya mendapatkan bukti gejala yang ditunjukkan oleh ketidakberhasilan beberapa karyawan dalam membagi perannya dan menghadapi tekanan. Gejala tersebut ditunjukkan dengan adanya keluhan gangguan kesehatan (R1), sulit tidur dan sering memikirkan pekerjaan sebelum tidur (R2), pekerjaan kantor yang sering menganggu waktu istirahat hingga terbawa mimpi (R3), luapan emosi akibat tekanan kerja juga dirasakan oleh rekan kerja (R4), kesulitan membagi waktu antara pekerjaan dan kehidupan pribadi (R5), adanya komplain dari keluarga karena dirasa lebih mementingkan pekerjaan (R3), dan tekanan dari workload yang selalu menuntut pencapaian target membuat seorang karyawan merasa lelah fisik dan pikiran (R2).

Adanya tekanan dari workload dianggap sebagai hal yang serius untuk diperhatikan dan menjadi masalah yang penting. Menurut Muhr et al. (2013), workload yang tinggi dari seorang karyawan harus dianggap sebagai hal yang serius untuk dikelola karena organisasi mengklaim hanya memiliki kontrol sedikit atas hal tersebut. Walaupun work life balance menjadi isu yang penting di kalangan kaum milenial saat ini, namun penelitian yang membahas work life balance karyawan milenial level manajerial masih sangat terbatas (Myers, 2010). Hasil penelitian yang dilakukan cenderung menghasilkan outcomes psikologis berupa stres sebagai hasil dari ketidakseimbangan seseorang (Bruening \& Dixon, 2007). Masih sedikit penelitian yang membahas mengenai pemaknaan atas work life balance dan upaya untuk mengurangi konflik dari setiap domain kehidupan (Grady \& McCarthy, 2008). Perbankan syariah bukan hanya sebagai tempat kerja sesuai dengan syariat Islam, namun sebagai sistem yang berlandaskan pada dasar spiritual dan operasional (Abubakar, 2017). Secara spiritual, perbankan syariah berkomitmen untuk menjalankan bisnisnya berdasarkan dua prinsip, yaitu Halal dan Tayib. Prinsip dasar Halal yang dimaksud adalah Bank Syariah melarang melakukan kegiatan bisnis yang tidak sah yang mengandung unsur - unsur yang dilarang oleh syariat Islam. Sedangkan prinsip dasar Tayib mencakup dua aspek, yaitu Ihsan yang artinya memberikan yang terbaik dan Tawazun yang artinya seimbang antara spiritual dan material (KNKG, 2011).

Berdasarkan penjelasan tersebut, maka secara tersirat menerangkan bahwa perbankan syariah juga memperhatikan pemenuhan work-life balance individu karyawan yang menuntut keseimbangan dari aspek spiritual dan kesejahteraan psikologis. Akan tetapi, landasan tersebut tidak mencerminkan hasil pra-penelitian yang telah dijelaskan sebelumnya. Berdasarkan hasil prapenelitian dari karyawan milenial manajerial BTN Syariah, didapatkan bukti gejala yang ditunjukkan oleh ketidakberhasilan beberapa karyawan dalam membagi perannya dan menghadapi tekanan dari tempat kerja. Mengingat karakteristik dari generasi milenial yang lebih menuntut work life balance dan merasa lebih sulit dalam menghadapi tekanan kerja, maka akan menjadi burder yang tidak dapat dihindari oleh kaum milenial level manajerial (Smith, 2018). Fenomena para kaum milenial level manajerial yang tetap bertahan dengan beban kerja yang tinggi dan gejala ketidakberhasilan dalam pembagian multi perannya menjadi menarik untuk diteliti lebih lanjut, jika dikaitkan dengan bagaimana pemaknaan work life balance yang dilakukan karyawan milenial level manajerial di lingkungan kerja syariah yang dianggap mendukung pemenuhan keseimbangan dari aspek spiritual dan kesejahteraan (Abu-Bakar, 2017).

Oleh karena itu, penelitian ini menjadi penting bagi kaum milenial level manajerial agar dapat menjadi pedoman untuk memahami kondisi work life balance yang mereka alami dan bagaimana kaum milenial mengelola kondisi tersebut dalam usahanya menghadapi hambatan work life balance. Penelitian ini juga memiliki implikasi bagi organisasi, khususnya yang berbasis syariah dalam memahami perilaku dan kebutuhan kaum milenial level manajerial. Selain itu, 
penelitian ini akan mengisi gap pada literatur yang berfokus pada subyek generasi milenial level manajerial dengan mengeksplorasi secara mendalam bagaimana kaum milenial level manajerial tersebut memaknai work-life balance yang nantinya akan menghasilkan output berupa esensi atau inti sari dari pengalaman work-life balance yang dialami.

\section{TINJAUAN PUSTAKA}

Work-life balance merupakan sebuah konsep yang didefinisikan dengan cara yang berbeda beda oleh penelitian sebelumnya. Work-life balance awalnya disebut sebagai work-family conflict (Clark, 2000). Integrasi atau keseimbangan antara pekerjaan dan kehidupan didefinisikan sebagai proses rekonsiliasi pekerjaan, keluarga, dan tuntutan waktu kehidupan pribadi (Grady dan McCarthy, 2008). Menurut Kirchmeyer (2000), work-life balance diartikan sebagai pencapaian pengalaman yang memuaskan di semua domain kehidupan dan untuk melakukannya memerlukan sumber daya pribadi seperti energi, waktu, dan komitmen untuk terdistribusi dengan baik di seluruh domain. Sedangkan menurut Kofodimos (1993), work-life balance mengacu pada kehidupan yang memuaskan, sehat, dan produktif yang mencakup bekerja, bermain, dan bersosialisasi. Istilah worklife balance mengacu pada individu yang menghabiskan waktu yang cukup di pekerjaan mereka dan kegiatan lain di luar pekerjaannya, seperti keluarga, lingkungan sosial, dan hobi karena setiap orang memiliki 24 jam per hari yang sama untuk menghabiskan waktu dalam pemenuhan orientasinya. Konsep work-life balance semakin berkembang, work-life balance tidak hanya mengenai konflik peran dan keterlibatan peran. Namun, work-life balance diartikan sebagai sejauh mana efektivitas dan kepuasan individu dalam berbagai peran atau bidang kehidupan dapat konsisten dengan nilai - nilai kehidupan atau prioritas mereka (Adkins, 2019). Konsep lain datang dari Wayne et al. (2017) yang menjelaskan bahwa definisi work-life balance merupakan suatu keadaan keseimbangan yang didefinisikan sendiri oleh masing - masing individu. Dengan demikian, keseimbangan tidak hanya didefinisikan sebagai kesetaraan antara pekerjaan, keluarga, dan kehidupan pribadi, tetapi keseimbangan yang diinginkan antara domain kehidupan dan karir individu.

Menurut Joshi et al. (2002), work-life balance didasarkan pada keyakinan bahwa pekerjaan merupakan hal yang penting. Namun, pencapaian dan kenikmatan dalam kehidupan sehari-hari merupakan hal yang lebih penting bagi kesejahteraan psikologis. Kesesuaian antara tuntutan dan sumber daya dari seseorang dirasa penting dalam mencapai keseimbangan (Adkins, 2019). Keseimbangan kehidupan kerja merupakan hal yang penting karena mempengaruhi kesejahteraan individu (Allan, 2007). Work-life balance mencerminkan orientasi individu di berbagai perannya yang berbeda yang disebut sebagai fenomena antar peran (Marks dan MacDermid, 1996; Greenhaus et al., 2002). Work-life balance menyiratkan individu mengurangi domain pekerjaan mereka untuk menghabiskan lebih banyak waktu bersama keluarga dan kehidupan pribadinya. Work life balance didefinisikan sebagai pemenuhan kepuasan dan fungsi yang baik di tempat kerja maupun di rumah dengan konflik peran yang minimal (Clark, 2001). Peran yang dimaksud adalah sebuah nilai-nilai yang dipegang individu mengenai domain pekerjaan dan keluarga berdasarkan pada apa yang diyakini penting dan menjadi prioritas dalam kehidupan seorang individu (Carlson dan Kacmar, 2000). Akumulasi peran dapat menghasilkan outcomes positif dimana seorang individu dapat menemukan kepuasan, baik dari pekerjaan dan kehidupan pribadi yang mengarah ke peningkatan tingkat kebahagiaan, kepuasan hidup, dan persepsi kualitas hidup (Greenhaus dan Powell, 2006). Menurut Clark (2001), terdapat lima dimensi work-life balance diantaranya worksatisfaction, home satisfaction, family functioning, role-conflict, dan employee citizenship.

Menurut Greenhaus et al. (2002), work-life balance tersusun dari tiga komponen, yaitu time balance, involvment balance, dan satisfaction balance. Adapun (1) time balance merupakan jumlah waktu yang setara untuk pekerjaan dan peran lainnya, (2) involvment balance merupakan tingkat keterlibatan psikologis yang setara dalam pekerjaan dan peran lainnya, (3) satisfaction balance merupakan tingkat kepuasan yang setara dengan pekerjaan dan peran lainnya. Setiap komponen keseimbangan work-life dapat mewakili keseimbangan positif atau negatif tergantung pada apakah tingkat waktu, keterlibatan, atau kepuasan yang sama tingginya atau sama rendahnya.

Berdasarkan penelitian empiris, literatur, konsep, dan teori yang telah dipaparkan, terdapat gap yang perlu untuk diteliti lebih lanjut, yaitu mengenai pemaknaan work-life balance dan 
hambatan yang ditemui dalam mencapai work-life balance, terutama pada kaum milenial level manajerial. Pemaknaan merupakan konsep yang relatif jarang dibahas dan dieksplorasi secara mendalam. Oleh karena itu, untuk mengisi gap tersebut diusulkan pertanyaan penelitian sebagai berikut:

1. Bagaimana karyawan milenial level manajerial Bank Tabungan Negara Syariah memaknai worklife balance?

2. Hambatan apa saja yang dihadapai oleh karyawan milenial level manajerial Bank Tabungan Negara Syariah dalam memenuhi work-life balance?

\section{In-depth Interview}

\section{METODE PENELITIAN}

Metode yang digunakan untuk mengumpulkan data dan informasi dalam penelitian ini adalah dengan wawancara mendalam (in-depth interview). Menurut Moleong (2011), wawancara adalah metode yang digunakan berdasarkan laporan verbal dimana terdapat hubungan secara langsung antara peneliti dan subyek yang ingin diteliti. Kvale dan Brinkmann (2009) menyarankan wawancara dilakukan secara kolaboratif, dimana peneliti dan informan cenderung seimbang dalam proses pertanyaan, penafsiran, dan pelaporan sehingga menghasilkan hasil wawancara yang relevan. Dengan menggunakan in-depth interview, peneliti diharapkan akan mendapatkan data yang lebih mendalam dan spesifik. Wawancara dilakukan melalui percakapan oleh dua pihak, antara pewawancara (interviewer) yang mengajukan sejumlah pertanyaan dan informan kunci yang diwawancarai yang memberikan jawaban atas pertanyaan tersebut (interviewee). Dalam penelitian ini, wawancara mendalam (in-depth interview) dilakukan dengan informan kunci yang telah ditentukan. Dalam melakukan wawancara ada beberapa hal yang perlu diperhatikan, peneliti perlu mendengarkan informan secara teliti, mencatat apa yang disampaikan oleh informan, menggali informasi secara lebih mendalam, dan tidak membatasi opini yang dikemukakan informan. Dengan demikian, peneliti diharapkan dapat memperoleh informasi yang relevan dengan kebutuhannya (Creswell, 2015).

Bentuk pertanyaan dalam wawancara mendalam (in-depth interview) bersifat terbuka, karena informasi yang diharapkan bersiftat mendalam dari sudut pandang informan dan memiliki kebebasan berekspresi dalam menyampaikan informasi. Informan juga harus mengetahui dengan jelas terhadap tujuan dan maksud wawancara yang dilakukan kepada mereka. Selain itu, pertanyaan dalam penelitian ini bersifat semi terstuktur dimana wawancara yang dilakukan lebih bebas dibandingkan dengan wawancara terstruktur (Boyce dan Neale, 2006). Pertanyaan dalam wawancara ini terdiri dari dari main question dan probing question. Main question berupa poin pertanyaan utama yang ingin ditanyakan, probing question berupa poin pertanyaan pendukung untuk memperjelas dan menyelidiki informasi yang diberikan oleh informan. Wawancara semi terstruktur merupakan alat pengumpul data kualitatif yang membantu peneliti dalam mengumpulkan informan secara detil dan sesuai konteks berdasarkan cerita maupun pengalaman informan (Cohen et al., 2007).

\section{Research Context}

Penelitian ini merupakan penelitian kualitatif yang menggunakan pendekatan fenomenologi. Menurut Creswell (2015), pendekatan fenomenologi digunakan karena bertujuan untuk menggali pengalaman dari sudut pandang seseorang yang membentuk sebuah pemaknaan individual. Pendekatan fenomenologi mendeskripsikan pemaknaan umum dari sejumlah individu terhadap berbagai pengalaman hidup mereka terkait dengan konsep atau fenomena work-life balance. Tujuan utama dari studi fenomenologi adalah untuk mereduksi pengalaman individu dari sudut pandang individu menjadi deskripsi tentang esensi atau makna atas fenomena. Deskripsi ini terdiri dari "apa" yang mereka alami dan "bagaimana" mereka mengalaminya. Pengambilan data dilakukan secara in-depth interview dalam bidang sumber daya manusia, khususnya kondisi worklife balance yang dialami oleh karyawan milenial level manajerial pada Bank Tabungan Negara Syariah: Kantor Cabang Syariah Surabaya. Pengambilan data dilakukan secara in-depth interview karena sifatnya tidak dibatasi oleh masalah dan pertanyaan yang diajukan, dimana peneliti dibebaskan untuk menggali topik yang diteliti. Selain itu, in-depth interview bertujuan untuk 
menemukan permasalahan secara lebih terbuka dan luas (Creswell, 2015). Konsep work-life balance yang dimaksud ialah bagaimana idealisme pencapaian hidup yang seimbang dan kepuasan dalam pencapaian semua domain kehidupan, khususnya kehidupan profesional pekerjaan, kehidupan keluarga, kehidupan sosial, dan kehidupan beragama.

\section{Sampling Method}

Pemilihan informan sebagai sumber data dalam penelitian ini berdasarkan pada subyek yang bersedia memberikan informasi yang akurat, menguasai permasalahan, dan memiliki data atas permasalahan tersebut. Penelitian kualitatif tidak mempermasalahkan jumlah informan, namun perlu memperhatikan dalam ketepatan pemilihan informan kunci dan kompleksitas dari keragaman fenomena sosial yang diteliti. Informan pada penelitian ini memiliki kriteria khusus, sehingga teknik yang digunakan adalah purposive sampling. Teknik purposive sampling mempertimbangkan kriteria - kriteria sampling yang mencakup partisipan dalam sampel, tipe spesifik sampel, dan ukuran sampel. Kriteria purposive sampling pada studi fenomenologi dilakukan dengan memastikan semua partisipan mengalami fenomena yang akan diteliti (Etikan et al., 2016). Dalam penelitian ini, terdapat 10 narasumber yang menjadi key informan dari jumlah populasi sebanyak 12 orang milenial level manajerial yang bekerja di Bank Tabungan Negara Syariah: Kantor Cabang Syariah Surabaya. Pemenuhan kriteria purposive sampling dilakukan dengan memastikan bahwa semua partisipan mengalami fenomena yang diteliti. Dari jumlah populasi 12 orang karyawan milenial level manajerial, hanya terdapat 11 orang karyawan level manajerial yang tergolong memiliki kriteria sample, dimana 1 orang lainnya masih berstatus lajang.

Setelah menetapkan kriteria sampling, selanjutnya dilakukan proses pengumpulan data dengan melakukan wawancara mendalam (in-depth interview) dengan 11 orang karyawan level manajerial yang memenuhi kriteria. Namun, terdapat 1 orang karyawan yang enggan menjadi key informan karena dirinya merasa hidupnya baik - baik saja dan tidak merasa gagal dalam pencapaian work-life balance. Dengan demikian, dapat ditetapkan sebanyak 10 orang karyawan yang memenuhi kriteria - kriteria sampling. Adapun kriteria yang digunakan dalam penelitian ini adalah sebagai berikut:

1. Narasumber merupakan kelompok generasi milenial yang lahir dalam rentan waktu mulai tahun 1980 sampai dengan tahun 1995

2. Narasumber merupakan karyawan yang bekerja di Bank Tabungan Negara Syariah: Kantor Cabang Syariah Surabaya dan berstatus sebagai pegawai tetap

3. Narasumber merupakan karyawan yang menduduki posisi level manajerial

4. Narasumber telah menikah dan memiliki peran di dalam keluarga

5. Karyawan milenial level manajerial yang menjadi narasumber harus menunjukkan indikasi adanya hambatan yang ditemui dalam upayanya memenuhi work-life balance. Hal ini dapat diketahui setelah narasumber menjawab pertanyaan pembuka yang diajukan peneliti pada saat proses wawancara

\section{HASIL DAN PEMBAHASAN}

Temuan direpresentasikan sesuai dengan tujuan penelitian dan pertanyaan penelitian. Pertama, akan dipaparkan mengenai hal apa saja yang mendasari individu memaknai work-life balance dan bagaimana manifestasi pemaknaan atas konsep work-life balance tersebut. Kemudian akan diikuti dengan penyebab yang menghambat terjadinya work-life balance yang dikaitkan dengan konflik peran, isu kesehatan yang muncul, dan bagaimana cara yang digunakan individu dalam usahanya memenuhi work-life balance. Berdasarkan hasil wawancara mendalam terhadap narasumber dapat diketahui bahwa setiap narasumber memaknai work-life balance sebagai pencapaian atas domain kehidupan yang dimiliki. Domain kehidupan tersebut dianggap seimbang apabila semua domain dapat berjalan selaras tanpa adanya masalah yang berarti. Faktor individual dan organisasi menjadi stimulus bagi narasumber dalam memaknai dan membentuk manifestasi terkait work-life balance.

Keberhasilan atas domain keluarga digambarkan oleh narasumber sebagai hubungan keharmonisan keluarga, kemakluman yang diberikan oleh anggota keluarga, dan kesuksesan dalam mendidik anak sebagai wujud terpenuhinya tanggung jawab peran dalam keluarga. Keberhasilan 
atas domain pekerjaan digambarkan oleh narasumber sebagai kesuksesan karir pekerjaan, tercapainya target pekerjaan, kenyamanan dan kebahagiaan dalam bekerja. Keberhasilan atas domain pribadi mencakup hubungan sosial yang digambarkan oleh narasumber sebagai hubungan kedekatan dengan lingkungan sosial, kepuasan atas penyaluran hobi dan ketertarikan pribadi sebagai wujud kebahagiaan yang diharapkan dari pemenuhan kehidupan sosial. Sedangkan keberhasilan atas domain spiritual digambarkan oleh narasumber sebagai hubungan yang dibangun dengan Tuhan dan sesama manusia, terpenuhinya kualitas beribadah, dan kebahagiaan lahir batin. Hasil untuk skema pemaknaan work-life balance digambarkan pada Gambar 1 di bawah ini:

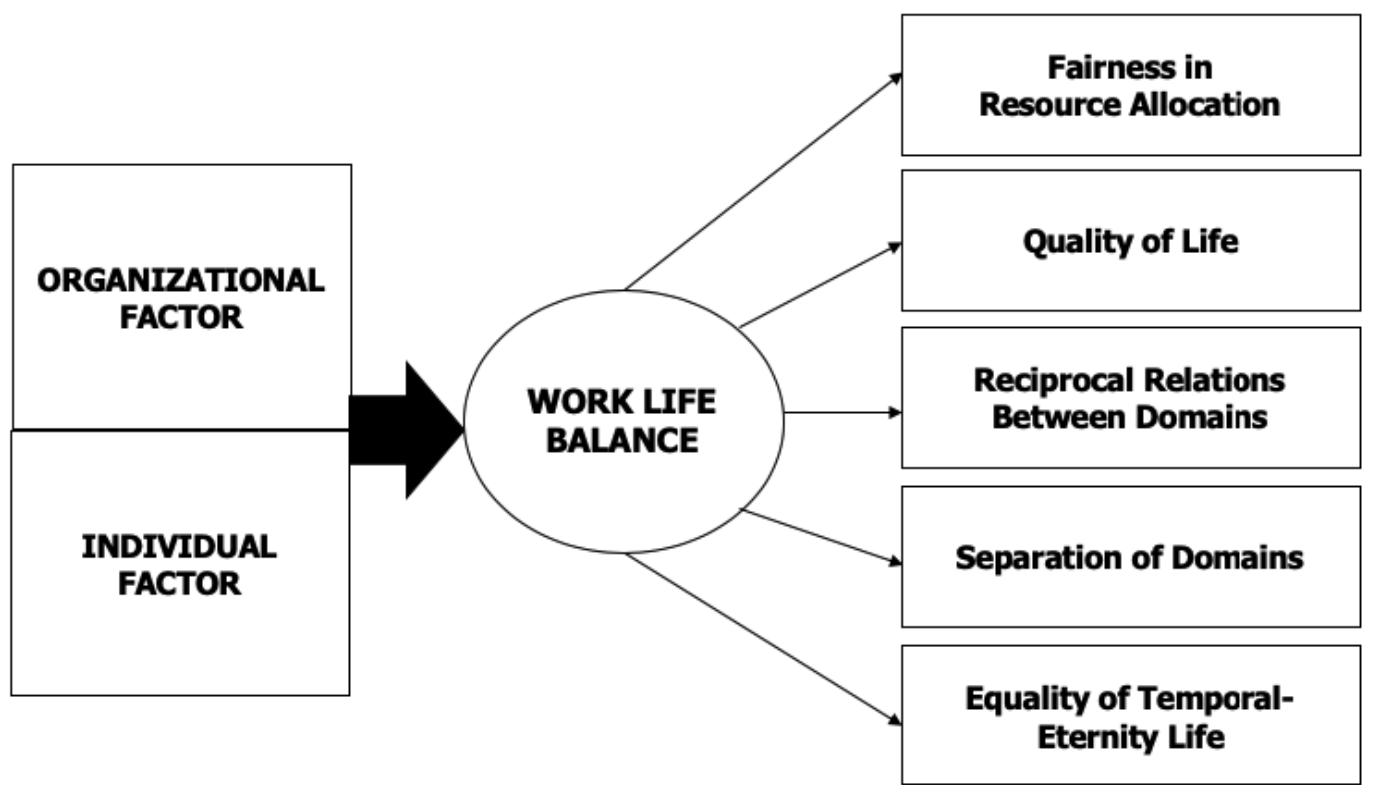

Gambar 1. Pemaknaan Work-Life Balance

Narasumber menyampaikan bahwa dirinya akan berada pada titik keseimbangan apabila berhasil membagi resource yang dimiliki secara adil merata. Apabila narasumber tidak mampu membagi waktu, perhatian, energi, dan komitmen secara adil maka dapat dikatakan bahwa dirinya belum mencapai keseimbangan hidup yang diharapkan seperti yang disampaikan oleh narasumber (NS1) di bawah ini: "Kalo menurut saya yang ideal, saya bisa membagi waktu - waktu tersebut. Jadi ketika saya ngga berhasil membagi waktu antara pekerjaan, keluarga, dan akhirat, menurut saya ngga bisa seimbang. Ketika saya bisa membuat waktu tersebut, ada kepuasan yang saya dapatkan. Jadi pembagian waktu yang adil ketiga sunnah tersebut." (NS1)

Kualitas hidup merupakan wujud dari outcomes yang diperoleh narasumber dan pihak pihak lainnya yang memiliki keterlibatan psikologis di dalam domain kehidupan. Salah seorang narasumber mengutarakan bahwa dirinya tidak akan pernah bisa mencapai keseimbangan hidup apabila hanya diukur secara kuantitas berdasarkan pembagian waktu yang merata. Momen kebersamaan yang dimiliki menjadi salah satu hal yang menjadi dasar bagi narasumber dalam memaknai kualitas waktu yang diperoleh bersama keluarga. Kualitas waktu yang didapatkan narasumber tersebut mampu menjelma menjadi rasa kebahagiaan seperti yang disampaikan oleh narasumber (NS10) berikut: "Kalo dari waktu jelas aku ngga seimbang, tapi dari kualitasnya ...... Jadi pada saat Sabtu - Minggu tuh yang penting ngumpul dan ngga beban, happy, ngga bete betean, yaudah happy. Kualitasnya sama - sama happy aja pokoknya. Jadi ada rasa kebahagiaan antara aku sama orang lain yang merasakan pada saat momen itu." (NS10)

Hal tersebut dipertegas oleh narasumber (NS3) lainnya: "Kualitas itu kita cari dari momen kita, misal main sama anak, main sama istri. Nah itu yang aku jadiin. Intinya momen lah, jadi momen 
sama keluarga. Itu yang aku hitung balance... momenku sama kerjaan momenku sama keluarga. Perhatiannya sama, udah kalo ngitung waktu ngga bakal ada." (NS3)

Hubungan timbal balik antar domain pun diartikan oleh narasumber (NS3) sebagai bentuk take and give antara dua komponen atau lebih. Tak dapat dipungkiri bahwa pekerjaan dan keluarga adalah dua bagian hidup yang tidak dapat dipisahkan. Dirinya beranggapan bahwa keseimbangan hidup dapat terjadi ketika kedua domain tersebut dapat saling memberikan implikasi yang positif. Implikasi yang dimaksud adalah domain pekerjaan dapat memberikan benefit berupa kesejahteraan yang baik untuk keluarga. Sedangkan domain keluarga dapat memberikan kemakluman untuk narasumber dalam menjalani peran kehidupan lainnya. Hal tersebut menyiratkan bahwa kesetaraan antara hak dan kewajiban juga menjadi dasar hubungan timbal balik positif yang diperoleh narasumber seperti yang disampaikan oleh narasumber (NS3) sebagai berikut: "Intinya antara kerjaan sama keluarga, itu kan dua komponen yang ngga bisa saya pisahkan. Idealnya istri paham sama kerjaan kita, kerjaan itu memberikan benefit yang sesuai dengan kerjaannya. Intinya seperti itu, take and give dari kedua komponen. Jadi kita harus menyadari antara hak dan kewajiban." (NS3). Hal tersebut dipertegas oleh narasumber (NS2) lainnya: "Artinya kalo pekerjaan kita optimal, otomatis nanti dalam berkeluarga maupun beribadah kita juga bisa mendapatkan hasil optimal. Kalo aku mengibaratkan kalo namanya pekerjaan kita outputnya kesejahteraan ya, nah kesejahteraan nanti larinya ke keluarga ataupun bisa dijadikan salah satu sarana dalam beribadah. Jadi saling berimplikasi positif antar aspek." (NS2)

Beberapa narasumber memaknai work-life balance sebagai bentuk batasan - batasan domain kehidupan yang dipisahkan secara jelas. Pemisahan domain yang dilakukan bertujuan untuk menempatkan posisi hak dan kewajiban secara jelas dari domain pekerjaan, keluarga, pribadi, dan spiritual. Pemisahan domain yang dilakukan tersebut menandakan bahwa narasumber ingin memberikan porsi yang jelas untuk setiap domain kehidupan tanpa mengurangi atau mengorbankan domain lainnya. Namun di sisi lainnya, pemisahan domain tersebut dapat membuat narasumber merasa bahwa dirinya belum berada di titik keseimbangan karena merasa timpang tindih atau lebih berat sebelah. Hal tersebut dapat terjadi karena salah satu domain dapat mengeliminir domain lainnya apabila narasumber tidak dapat memisahkan domain secara jelas, sehingga domain lainnya tidak berjalan dengan optimal seperti yang dijelaskan oleh narasumber (NS7) sebagai berikut: "Karena kalo ada yang dirasa ngga seimbang ya pasti akan ada minus lah di salah satu bagian hidup ya, entah itu di pekerjaan di keluarga atau di sosial pasti nanti akan terjadi timpang ......" (NS7). Hal tersebut dipertegas oleh narasumber (NS2) lainnya: "Kalo aku boleh menggambarkan atau mengistilahkan kehidupan itu harus ada keseimbangan sih ..... dalam hal harus punya batasan - batasan mana yang haknya mana kewajibannya. Harus sesuai dengan porsinya masing - masing. Artinya dari tiga aspek tersebut harus diberikan haknya. Jangan sampe di salah satu aspek atau hal tadi dikorbankan atau dikurangi hak atau porsinya ..... Jangan sampai kesannya nanti tumpang tindih atau mengeliminir satu sama lain." (NS2).

Konsep idealisme keseimbangan bagi narasumber tak lagi terpaku antara pekerjaan dan keluarga, bahkan lebih dari itu. Manifestasi yang tertanam pada narasumber melihat bahwa worklife balance tidak hanya dari sisi kehidupan duniawi saja, melainkan sisi kehidupan yang menjadi tujuan akhirnya untuk kehidupan yang kekal di akhirat dapat mengubah cara pandangnya. Terlebih ketika tujuan untuk bekerja tidak hanya sekedar mencari material saja, namun sekaligus memenuhi tujuan akhirnya untuk domain spiritual dengan bekerja sesuai dengan tuntunan agama seperti yang diutarakan oleh narasumber (NS1) di bawah ini: "Jadi ngga cuman kerja duniawi saja, jadi kalo diniatkan ibadah itu jadi ada dua tujuan, bisa dapat duniawi dan akhirat. Intinya dunianya dapat, akhiratnya juga dapat dengan bekerja sesuai dengan tuntunan syariah." (NS1). Hal tersebut dipertegas oleh narasumber (NS7) lainnya: "Kalo dari saya sih mbak untuk work-life balance, pertama ya bekerja sesuai dengan Islam sendiri itu kan memang sudah kewajiban dan disampaikan kalo kita harus bagus dalam Hablum Minallah dan Hablum Minannas ...... Makanya kalo kerja diniatkan ibadah itu kan sebagai bentuk kita ibadah kepada Allah yang mencakup Hablum Minallah. Kalo untuk yang Hablum Minannas itu kan hubungan kita dengan pekerjaan, keluarga, sosial ......" (NS7).

Selanjutnya, pertanyaan penelitian yang akan dijawab dalam penelitian ini juga berusaha untuk menjawab hambatan apa saja yang menyebabkan ketidakberhasilan work-life balance yang 
terkait dengan konflik peran, isu kesehatan yang muncul, dan bagaimana cara yang digunakan individu dalam usahanya memenuhi work-life balance. Hasil untuk skema hambatan work-life balance digambarkan pada Gambar 2 di bawah ini:

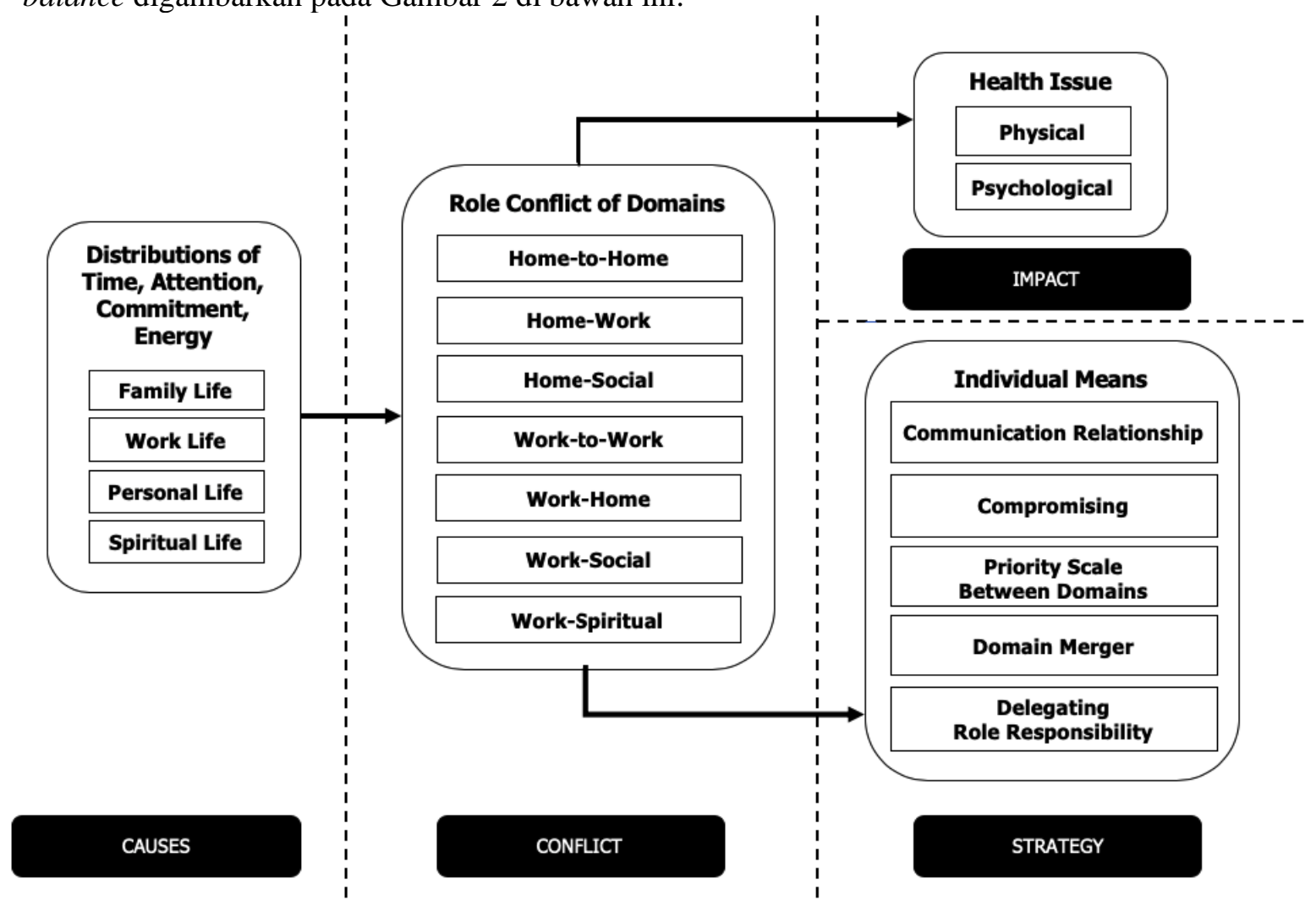

Gambar 2. Hambatan Work-Life Balance

Setiap narasumber memiliki keterbatasan diri masing - masing dalam membagi waktu, perhatian, komitmen, dan energi untuk memenuhi seluruh domain kehidupan. Keterbatasan sumber daya diri tersebut berpotensi menghambat keseimbangan hidup mereka karena ketidakberdayaan diri dalam memenuhi domain kehidupan. Apabila narasumber tidak dapat memberikan waktu yang cukup untuk keluarga, maka narasumber juga tidak dapat memberikan perhatian seutuhnya untuk keluarga. Perhatian yang diberikan merupakan salah satu upaya seseorang untuk memanfaatkan waktu yang dimilikinya terhadap keluarga. Hal tersebut dialami oleh salah seorang narasumber (NS1) yang merasa kesulitan untuk membagi waktu dan perhatiannya: "Ketika kondisi dulu saat saya lagi pas pernah mengalami banyak banget kerjaan ya artinya waktunya kan berkurang ...... Kalo waktu berkurang pasti kan perhatian juga berkurang karena kesibukan yang mengharuskan waktu tersita banyak di pekerjaan." (NS1). Bagi beberapa narasumber yang telah memiliki anak, terutama bagi ibu yang bekerja akan lebih merasakan sulitnya membagi waktu, perhatian, komitmen, dan energi mereka untuk keluarga. Narasumber yang merupakan working-mothers menyadari bahwa mereka memiliki keterbatasan waktu dan perhatian untuk keluarga, terutama anak. Mereka merasa bahwa waktu kebersamaan yang dimiliki untuk anak sedikit. Peran sebagai ibu merupakan peran utama yang tidak tergantikan dan menuntut banyak waktu. Hal tersebut diutarakan oleh salah seorang narasumber (NS10) sebagai berikut: "Yang paling berat peran sebagai ibu karena itu ngga bisa digantikan. Kita memang harus ada untuk menjadi seorang ibu dan ngga bisa dialihkan. Hal itu memakan waktu yang banyak dan menguras tenaga." (NS10). Hal tersebut dipertegas oleh narasumber (NS8) lainnya: "Keluarga itu kan berarti adanya waktu dan perhatian kita buat suami dan anak - anak agar mereka itu ngga merasa kesepian. Duh, kalo ditanya aku sedih. Gimana ya, kalo sekarang tuh rasanya ya aku belum bisa mencurahkan semua perhatianku ke anak - anak karena terbatas di pekerjaanku ini.” (NS8) 
Keterbatasan waktu yang dimiliki oleh para narasumber dalam menyalurkan hobi, ketertarikan, atau kesenangan pribadi menjadi suatu tantangan tersendiri yang sulit untuk diwujudkan. Hal ini disebabkan oleh adanya aspek kehidupan lain yang dirasa lebih penting dan tidak dapat ditinggalkan seperti keluarga dan pekerjaan. Narasumber merasa bahwa komunitas bukanlah suatu sarana yang tepat untuk menyalurkan ketertarikan karena akan mengeliminir waktu untuk keluarga. Mereka juga mengeluhkan kelelahan fisik setelah bekerja sehingga tidak mampu untuk menyalurkan kesenangan pribadi mereka.

Keterbatasan energi tersebut akan mengorbankan kehidupan pribadi yang menjadi salah satu concern utama bagi generasi milenial. Preferensi dalam memprioritaskan dan mendistribusikan waktu, perhatian, komitmen, dan energi terhadap aspek kehidupan pribadi bagi generasi milenial akan berubah ketika sudah berkeluarga. Hal tersebut disampaikan narasumber (NS3) berikut:"Mending daripada aku sama komunitas, aku sama keluargaku sama teman temanku sendiri. Kalo sama komunitas wasting time. Udah capek habis kerja, jadi udah ngga keturutan ..... udah ngga bisa tersalurkan semuanya." (NS3). Hal tersebut dipertegas oleh narasumber (NS8) lainnya: "Habis waktuku hanya buat kantor dan keluarga. Kalo sebelum nikah iya aku masih punya prioritas untuk sama temen - temen, tapi setelah ini ngga ada mentingin sosial blasss." (NS10)

Selain itu, narasumber mengakui bahwa tanggung jawab pekerjaan level manajerial ini akan lebih banyak menyita waktu dan perhatian, sehingga dirinya merasa kesulitan untuk menyalurkan kebutuhan spiritual melalui suatu komunitas rohani. Hal tersebut tidak dapat dihindari oleh narasumber karena mandat pekerjaan yang diberikan untuknya harus dipenuhi dengan penuh tanggung jawab dan amanah. Dirinya menyayangkan keterbatasan waktu yang dimiliknya dalam memenuhi aspek spiritual tersebut karena tuntutan pekerjaan seperti yang disampaikan oleh narasumber (NS5) sebagai berikut: "Selain dari pemenuhan hobi, pemenuhan ikut komunitas rohani yang disarankan keluarga sebenernya bisa semua dilakuin. Cuman karena keterbatasan waktu dan jabatan yang sekarang diamanahkan di pekerjaan, jadi akhirnya semuanya belum bisa terpenuhi satu - satu. Ya masih menata lah, menata itu semua." (NS5)

Tuntutan pekerjaan narasumber sebagai karyawan perusahaan yang berada di level manajerial yang mengemban jabatan manajerial akan mempengaruhi kondisi kesehatan fisik maupun kesehatan psikologis setiap individu. Ketika narasumber mendapatkan beban kerja yang berlebih secara kuantitatif dan kualitatif seperti adanya desakan tenggat waktu yang harus dipenuhi, target pekerjaan yang melampaui kemampuan individu, dan kompleksitas permasalahan pekerjaan yang baru akan mempengaruhi kondisi kesehatan fisik individu. Hal ini erat kaitannya dengan kelelahan kerja (burnout) yang menyebabkan kondisi kesehatan fisik seseorang menurun. Dampak terhadap kesehatan fisik individu merupakan suatu hal yang harus dianggap serius dan menjadi perhatian karena rentan terjadi pada narasumber (NS2) yang diutarakan sebagai berikut: "Artinya meskipun ngga keluar kantor tapi karena ada deadline, terus kemudian dikejar target, menghadapi permasalahan - permasalahan yang dampaknya selain ke pikiran kan pasti juga larinya ke fisik juga nantinya." (NS2).

Perasaan tertekan yang dirasakan oleh beberapa narasumber karena berbagai macam tuntutan pekerjaan dapat menyebabkan stres. Stres yang timbul merupakan salah satu dampak ketidakseimbangan hidup karena narasumber tidak dapat menyalurkan aspek kehidupan lainnya seperti keluarga dan spiritual yang disebabkan oleh tuntutan pekerjaan yang berlebih. Oleh karena itu, work-life balance menjadi suatu hal yang esensial dan perlu diperhatikan untuk menunjang kesehatan psikologis seseorang. Hal tersebut didukung oleh pernyataan salah seorang narasumber (NS8) sebagai berikut: "Ya kalo dibilang seberapa penting harusnya penting sih. Hidup itu harus seimbang biar ngga stress. Cuman ya itu, mau gimana lagi, kalo sekarang sih memang aku melihat hidupku belum seimbang dan belum menuju ke arah keseimbangan itu." (NS8). Hal tersebut dipertegas oleh pernyataan narasumber (NS9) sebagai berikut: "Kalo kita tidak seimbang pasti stress. Misalnya pekerjaan dituntut ini itu banyak, akhirnya stress kan kepikiran kerjaan. Padahal kan kita punya sisi kehidupan yang lain, keluarga punya, religi punya. Ketika kita udah mikir pekerjaan tok atau mikir keluarga tok, akhirnya salah satu ngga beres." (NS9).

Tuntutan peran terhadap setiap domain yang terkadang tumpang tindih akan memaksa narasumber untuk menemukan cara terbaik untuk mengatasi tantangan tersebut. Tuntutan 
pembagian multi peran yang harus dilakukan oleh narasumber memang bukanlah hal yang mudah, namun hal tersebut tidak akan menjadi masalah yang berarti ketika narasumber dapat menemukan cara terbaik untuk mengatasinya dengan membangun hubungan komunikasi, melakukan kompromi yang didasari komitmen, dan mendelegasikan tanggung jawab peran. Selain itu, sebagain besar narasumber juga menetapkan skala prioritas dan meleburkan hubungan antar domain kehidupan.

\section{Pembahasan}

Studi ini menjawab dua research question utama. Research question pertama terjawab dengan dibentuknya tema pemaknaan terkait dasar pemaknaan konsep work-life balance dan manifestasi pemaknaan terhadap work-life balance. Setiap individu memiliki dasar pemaknaan atas work-life balance yang berbeda dan unik berdasarkan individual factor dan organizational factor yang telah dikelompokkan dalam temuan penelitian ini. Faktor individu adalah faktor yang berasal dari internal diri seseorang mencakup jenis kelamin, karakteristik generasi, latar belakang keluarga, dan status pernikahan. Sedangkan faktor organisasi adalah faktor yang berasal dari eksternal diri seseorang mencakup lingkungan tempat kerja individu yang terdiri dari budaya organisasi, karakteristik organisasi, sistem dan kebijakan organisasi. Kedua temuan faktor tersebut dapat mempengaruhi perspektif individu dalam mentransformasikan sebuah makna keseimbangan hidup.

Penelitian yang dilakukan oleh Adkins (2019) mendukung temuan penelitian ini yang menjelaskan bahwa "work-life balance is affected by a wide range of factors including individual values, life and career stage, and family structure". Berbagai faktor individual tersebut dapat mempengaruhi bagaimana sikap dan pemaknaan individu yang digunakan untuk mencapai keseimbangan hidup yang diinginkan. Namun sikap dan pemaknaan yang dimiliki individu dapat dibatasi oleh faktor situasional yang mencakup lingkungan organisasi seperti struktur pekerjaan dan kebijakan organisasi (Adkins, 2019). Setiap individu memiliki profil yang berbeda yang mencerminkan pendekatan atau pemaknaan mereka dalam mengelola batasan antara domain pekerjaan dan non-pekerjaan (Kossek et al., 2017). Dalam temuan penelitian, faktor individual mencakup berbagai hal yang mendasari individu dalam memaknai work-life balance. Keseimbangan peran yang dijalani di setiap domain kehidupan dipengaruhi oleh beberapa hal seperti apakah individu memiliki pasangan yang bekerja (dual-career couple), usia anak, hubungan kedekatan dengan anggota keluarga, dan tuntutan pengasuhan orang tua (Adkins, 2019).

Kemudian, faktor organisasi dirasa mempengaruhi individu dalam menyikapi dan memaknai work-life balance. Temuan penelitian ini menunjukkan bahwa aktivitas atau kebiasaan kerohanian yang dilakukan pada lingkungan BTN Syariah dapat memberikan dorongan bagi individu untuk meningkatkan kualitas spiritualnya karena nilai - nilai atau keyakinan yang tertanam pada lingkungan kerja. Temuan tersebut didukung oleh penelitian Sulistyo (2017) yang menjelaskan bahwa suatu organisasi harus selalu membangun dan memperkuat nilai - nilai budaya organisasi dan spiritual karyawan agar memiliki lebih banyak makna dalam kehidupan dan makna dalam pekerjaan. Norma atau nilai yang berlaku pada suatu organisasi juga dapat mendukung maupun menghambat penggunaan sumber daya individu yang dimiliki (Thompson et al., 1999).

Nilai "bekerja adalah ibadah" adalah hal yang diyakini individu ketika bekerja di lingkungan syariah yang dapat memberikan manfaat sekaligus memenuhi nilai agama sehingga dianggap sebagai ibadah. Individu yang meniatkan bekerja sebagai ibadah akan merasa lebih tenang dan nyaman bekerja di lingkungan kerja syariah karena tidak ada budaya senonoh yang dapat merugikan pihak lain atau menyalahi aturan. Budaya organisasi merupakan salah satu dukungan sosial yang dicari dan diharapkan individu dari lingkungan kerjanya untuk membentuk diri (Anand, 2019).

Adkins (2019) mendukung temuan bahwa setiap individu memiliki keinginan atas keseimbangan hidup antara domain pekerjaan, keluarga, dan pribadi. Setiap individu akan memiliki persepsi atas standar work-life balance berdasarkan keseimbangan hidup yang diinginkan. Namun, menurut penelitian Adkins (2019) menyebutkan bahwa bagaimana pun juga keseimbangan hidup yang diinginkan akan sulit dan tidak selalu bisa tercapai karena hal tersebut tergantung oleh fungsi sumber daya yang dimiliki apakah dapat saling mengisi secara substansial atau mengeliminir satu sama lain. 
Work-life balance dimaknai sebagai keadilan dalam pembagian sumber daya (fairness in resources allocation), pencapaian kualitas hidup (quality of life), hubungan timbal balik antar domain (reciprocal relations between domains), pemisahan domain kehidupan secara jelas (separation of life domain), keseteraan kehidupan duniawi dan akhirat (equality of temporaleternity life).

Fairness in resources allocation diartikan sebagai keadilan dalam mengalokasikan atau mendistribusikan personal resources yang dimiliki individu di seluruh domain kehidupan untuk mencapai keseimbangan hidup. Proses pengalokasian sumber daya tersebut memperhatikan semua tuntutan domain kehidupan (demands) sebagai hal yang harus diperlakukan secara adil baik tuntutan yang diinginkan (personal life) maupun tuntutan yang dibutuhkan (work life). Quality of life diartikan sebagai pencapaian kualitas hidup sebagai wujud dari outcomes yang diperoleh dari keberhasilan setiap domain kehidupan dan keterlibatan psikologis individu dengan pihak lainnya. Rasa kepuasan, kebahagiaan, kenyamanan adalah wujud dari kesejahteraan psikologis yang didapatkan atas kualitas hidup yang dirasakan oleh individu. Reciprocal relations between domains diartikan sebagai hubungan atau interaksi antar domain yang memberikan dampak positif terhadap individu. Keseimbangan positif akan terjadi ketika salah satu domain memiliki pengaruh positif terhadap domain kehidupan lainnya. Hubungan timbal balik antar domain mencerminkan hubungan timbal balik antar elemen yang membentuk sebuah keutuhan yang mencakup diri sendiri (sense of self), pekerjaan (the work itself), dan keseimbangan (the sense of balance) yang dirasakan individu. Separation of life domain diartikan sebagai pemisahan batasan domain kehidupan sesuai dengan porsi yang jelas tanpa mengurangi atau mengorbankan domain kehidupan lainnya. Batasan domain kehidupan mencakup batasan kognitif, fisik, dan perilaku individu dalam menempatkan posisi hak dan kewajiban setiap domain. Equality of temporal-eternity life diartikan sebagai kesetaraan kehidupan duniawi dan akhirat yang mencakup tujuan akhir dari kehidupan yang sesungguhnya. Kehidupan ditransformasikan tidak hanya sekedari aspek duniawi yang meliputi keluarga, pekerjaan, dan sosial. Namun kehidupan juga dimaknai sebagai tujuan akhir hidup yang mencakup aspek akhirat yang meliputi pemenuhan spiritualitas diri.

Selanjutnya, research question kedua terjawab dengan dibentuknya tema penyebab terhambatnya work-life balance, konflik peran antar domain, dampak ketidakberhasilan work-life balance, dan cara individu mengelola work-life balance. Hambatan yang ditemui narasumber dalam memenuhi work-life balance menjadi suatu penyebab atas ketidakberhasilan individu dalam mencapai keseimbangan hidup yang diharapkan. Pada penelitian ini ditemukan bahwa penyebab ketidakberhasilan tercapainya work-life balance adalah individu yang yang tidak dapat mendistribusikan waktu, perhatian, komitmen, dan energinya secara menyeluruh pada setiap domain kehidupan. Temuan ini didukung oleh Valcour (2007) yang menemukan bahwa kurangnya sumber daya diri yang dimiliki atau bentuk sumber daya yang tidak tersalurkan dapat memberikan kendala yang berarti bagi individu yang berusaha menjaga dan mencapai keseimbangan hidup. Temuan tersebut sejalan dengan penelitian Moen (2008) yang mengemukakan bahwa ketidaksesuaian dalam pengalokasian sumber daya dapat berujung konflik yang didasarkan oleh waktu, tekanan, dan perilaku dari suatu peran domain kehidupan.

Gangguan atau interference yang terjadi antar domain kehidupan tersebut menimbulkan konflik antar peran dalam domain yang sama maupun konflik antar peran dengan domain yang berbeda. Dalam temuan ini terdapat tujuh kategori konflik yang telah dikelompokkan yang mencakup domain pekerjaan dan non-pekerjaan seperti keluarga, sosial, spiritual. Temuan konflik peran tersebut didukung oleh penelitian Spieler (2018) yang mengembangkan alat pengukuran work-life balance dengan menggunakan empat kategori yang disebut personal life interference with work (PLIW), personal life enhancement of work (PLEW), work interference with personal life (WIPL), dan work enhancement of personal life (WEPL). Kelebihan beban kerja yang didapatkan individu secara konsisten berpengaruh signifikan terhadap timbulnya work-home interference (Geurts et al., 2003). Hal tersebut terjadi karena setiap individu memiliki life roles yang merupakan sistem nilai yang dipegang individu terkait domain pekerjaan dan non-pekerjaan berdasarkan pada apa yang dianggap penting atau prioritas oleh individu (Carlson \& Kacmar 2000). Dengan demikian, konflik antar peran merupakan hal yang harus dihindari oleh individu karena dapat mempengaruhi kesejahteraan individu dan organisasi (Allan, 2007). Penelitian terdahulu juga 
menggunakan teori identitas untuk menjelaskan bagaimana konflik antar peran dapat mempengaruhi individu dan menyebabkan masalah yang berhubungan dengan kesehatan, baik secara fisik maupun psikologis (Anand, 2019).

Keseimbangan yang diinginkan di antara domain kehidupan ditentukan secara individual dan mereka akan mengambil tindakan atau mencari cara untuk mencapai dan mempertahankan keseimbangan hidup tersebut. Dalam temuan penelitian ini, setiap individu menggunakan caranya tersendiri dalam usahanya mencapai keseimbangan hidup. Penelitian yang dilakukan oleh Adkins (2019) menjelaskan bahwa jika seseorang sudah merasa seimbang, maka dirinya akan berusaha untuk mempertahankan dengan cara melanjutkan usahanya tersebut melalui tindakan yang sama. Namun, jika seseorang merasa hidupnya belum seimbang, maka dirinya akan menyesuaikan tindakan yang menurutnya dapat mencapai keseimbangan yang diharapkan atau diinginkan.

\section{Kesimpulan}

Hambatan yang menjadi penyebab ketidakberhasilan pemenuhan work-life balance adalah keterbatasan individu dalam mendistribusikan personal resources yang dimiliki berupa waktu, perhatian, komitmen, dan energi pada seluruh domain kehidupan. Hambatan tersebut menyebabkan adanya konflik peran (role-conflict)dan menimbulkan dampak yang serius pada isu kesehatan individu. Konflik peran antar domain muncul ketika individu tidak dapat membagi personal resources dan memenuhi tuntutan multi peran yang dijalani sehingga akan menimbulkan konflik yang mencakup home-to-home, work-to-work, home-work, work-home, home-social, work-social, dan work-spiritual. Sedangkan, dampak yang ditimbulkan dari ketidakberhasilan individu mencapai work-life balance adalah isu kesehatan berupa gangguan kesehatan fisik dan psikologis yang disebabkan oleh gesekan peran dan interference yang terjadi antar domain.

Setiap individu memiliki cara yang unik dan berbeda dalam upayanya memenuhi work-life balance seperti membangun hubungan komunikasi, melakukan kompromi, menentukan skala prioritas antar domain, meleburkan atau mengintegrasikan domain, mendelegasikan atau membagi tanggung jawab dengan keluarga dan rekan kerja. Pemaknaan konsep work-life balance yang dilakukan setiap individu berbeda - beda yang didasari oleh faktor yang melekat pada individu (individual factor) dan faktor yang berasal dari lingkungan organisasi (organizational factor). Individual factor meliputi jenis kelamin, karakteristik generasi, latar belakang keluarga, dan status pernikahan. Sedangkan organizational factor mencakup budaya organisasi, karakteristik organisasi, sistem dan kebijakan. Work-life balance dimaknai sebagai keadilan dalam pembagian sumber daya (fairness in resources allocation), pencapaian kualitas hidup (quality of life), hubungan timbal balik antar domain (reciprocal relations between domains), pemisahan domain kehidupan secara jelas (separation of life domain), keseteraan kehidupan duniawi dan akhirat (equality of temporal-eternity life).

\section{Impikasi Akademis}

Penelitian ini memiliki kontribusi penting untuk mengisi research gap mengenai isu worklife balance dari kaum milenial level manajerial. Studi penelitian ini lebih jauh lagi berkontribusi pada literasi yang merujuk pada konsep work-life balance bagi milenial level manajerial yang berada di lingkungan kerja syariah. Temuan menarik pada penelitian ini adalah sebuah life ditransformasikan lebih jauh mencakup domain spiritual individu terlepas dari domain keluarga, pekerjaan, dan sosial. Domain spiritual masih belum diuraikan pada penelitian sebelumnya dan belum dijadikan sebagai dimensi domain kehidupan yang mendasari work-life balance. Namun, penelitian ini telah melengkapi penelitian Lyness (2013) yang menjelaskan bahwa fokus domain kehidupan non-pekerjaan mencakup kehidupan keluarga dan pribadi yang mencakup jenis kegiatan atau minat pribadi individu seperti pendidikan, sosial bermasyarakat, dan keagamaan.

Salah satu kontribusi penting dari sisi akademisi dari penelitian ini adalah berhasil membentuk tema dari penyebab terhambatnya work-life balance, konflik peran antar domain, dampak ketidakberhasilan work-life balance, cara individu mengelola work-life balance, dasar pemaknaan konsep work-life balance, dan manifestasi pemaknaan atas work-life balance. Penelitian ini juga berkontribusi untuk melengkapi literasi dengan menemukan bahwa latar belakang pekerjaan keluarga yang sejenis akan menjadikan kemakluman atas kondisi multi peran yang lebih baik, yang mana belum banyak dibahas oleh penelitian sebelumnya. Temuan menarik 
lainnya adalah karakteristik organisasi menjadi salah satu dasar individu memaknai konsep worklife balance. Dalam konteks ini, lingkungan kerja syariah memiliki karakteristik tersendiri yang membuat individu meyakini nilai "kerja adalah ibadah" yang mempengaruhi manifestasi pemaknaan individu atas work-life balance. Temuan baru lainnya dalam penelitian ini adalah manifestasi pemaknaan atas work-life balance yang diartikan sebagai kesetaraan kehidupan duniawi dan akhirat (equality of temporal-eternity life), yang mana belum dibahas pada penelitian sebelumnya.

\section{Impikasi Manajerial}

Penelitian tentang work-life balance generasi milenial level manajerial juga berkontribusi pada manajemen untuk mengelola sumber daya manusia organisasi dalam beberapa aspek. Pertama, terkait sistem dan kebijakan organisasi, sebaiknya pihak top management Bank Tabungan Negara Syariah melakukan pendekatan personal kepada seluruh lini manajemen setiap Kantor Cabang Syariah terkait dengan pentingnya dukungan sosial yang diberikan kepada karyawan berupa program family-friendly untuk menunjang keseimbangan hidup. Pendekatan dapat dilakukan dengan memberikan sosialisasi kepada manajemen Kantor Cabang Syariah akan pentingnya program family-friendly yang diberikan untuk karyawan. Kebijakan family-friendly yang dapat diterapkan berupa kegiatan ekstrakurikuler yang mendukung hobi atau minat karyawan, kegiatan kekeluargaan yang melibatkan antara karyawan dan keluarga, dan fasilitas penitipan anak bagi working-mother.

Kedua, sebaiknya pihak top management Bank Tabungan Negara Syariah memetakan asal daerah dan domisili setiap karyawan level manajerial sebagai pertimbangan atas penempatan wilayah kerja. Konsekuensi mengemban tanggung jawab level manajerial adalah bersedia ditempatkan di wilayah kerja seluruh Indonesia. Namun, hal tersebut dapat dipertimbangkan dengan melihat bagaimana kinerja dan prestasi yang dimiliki individu, sehingga dapat dilakukan penyesuaian penempatan wilayah kerja sesuai dengan daerah asal atau daerah terdekat agar mendekatkan mereka dengan keluarga.

Ketiga, sebaiknya pihak manajemen Kantor Cabang Syariah ketika memberikan jabatan tambahan atau jabatan (job grade) yang tidak sesuai dengan level posisi (person grade) diawali dengan tahapan penawaran jabatan kepada kandidat yang dirasa memenuhi kualifikasi untuk jabatan tertentu. Setelah kandidat bersedia menerima maka dapat dilanjutkan dengan penunjukkan dan penetapan kandidiat untuk menduduki posisi jabatan tersebut. Hal tersebut dirasa dapat menghindari work-overload yang diterima individu dalam mengemban tanggung jawab pekerjaan melebihi kapasitas atau kemampuan diri. Apabila individu mengemban tanggung jawab pekerjaan sesuai dengan kualifikasi atau kompetensinya, maka individu akan lebih optimal dan mudah mencapai tujuan organisasi dan work-life balance.

\section{Keterbatasan Penelitian dan Arah Bagi Penelitian Selanjutnya}

Penelitian ini tidak terlepas dari adanya keterbatasan. Keluarga merupakan salah satu hal yang dianggap privasi bagi sebagian besar orang sehingga membuat beberapa narasumber relatif tidak terbuka untuk mengungkapkan kehidupan berkeluarganya. Hal tersebut membuat peneliti harus cermat dan berhati - hati dalam menggali informasi yang sifatnya privasi agar tetap sesuai dengan tujuan penelitian. Peneliti sempat mendapatkan penolakan dalam penggalian informasi oleh salah seorang narasumber karena dirinya merasa enggan menceritakan kisah hidupnya terutama yang terkait dengan keluarga, sehingga peneliti tidak dapat mendapatkan informasi penuh dari narasumber.

Batasan pertama, penelitian ini hanya menggunakan populasi hanya dari satu kantor cabang dengan jumlah sample yang sedikit yaitu 10 orang karyawan milenial level manajerial. Penggunaan populasi yang lebih beragam dan jumlah sample yang lebih banyak akan memperluas lingkup penelitian sehingga dapat menghasilkan hasil yang lebih beragam dan kontekstual. Batasan kedua, narasumber dalam penelitian ini berasal dari unit kerja yang berbeda dengan perbandingan target pekerjaan dan kompleksitas masalah yang tidak sama. Hal tersebut menyebabkan workoverload yang dirasakan oleh setiap narasumber tidak serupa. Penggunaan subyek penelitian dengan work-overload yang sejenis disarankan bagi penelitian selanjutnya agar fenomena yang dihasilkan lebih mewakili. 
Batasan ketiga, penelitian ini terbatas pada generasi milenial yang berada di level manajerial. Padahal mayoritas level manajerial juga diduduki oleh generasi Xers, sehingga penelitian selanjutnya dapat mengkaji mengenai work-life balance dengan melakukan perbandingan antara generasi milenial dan generasi $\mathrm{X}$-ers yang berada di level manajerial. Hal tersebut dapat berkontribusi untuk work-life balance dengan pandangan yang berbeda. Selain itu, memperdalam faktor budaya dan karakteristik organisasi sebagai dasar pemaknaan konsep worklife balance merupakan hal yang menarik untuk diteliti lebih lanjut.

\section{DAFTAR PUSTAKA}

Abendroth, A., den Dulk, L. (2011) Support for The Work-Life Balance in Europe: The Impact of State, Workplace and Family Support on Work-Life Balance Satisfaction. Work, Employment, \& Society, Vol.25, 234-256

Abubakar, S., Setyowati, R., Rodliah, N., (2017) Sharia Governance on Islamic Banking: Spiritual Rights Perspective on Consumer Protection In Indonesia Diponegoro Law Review, Volume 02, Number 01

Adkins, L. Cheryl. Premeaux, F. Sonya. (2019) A Cybernetic Model of Work-Life Balance Through Time. Human Resource Management Review

Allan, Cameron. Loudoun, Rebecca. Peetz, David. (2007) Influences on Work/Non-Work Conflict. Journal of Sociology, Vol. 43(3): pp. 219-39

Allen, T., Herst, D., Bruck, C., Sutton, M. (2000) Consequences Associated with Work-to-Family Conflict: A Review and Agenda for Future Research. Journal of Occupational Health Psychology, Vol.5(2), 278-308

Allen, T.D., Armstrong, J. (2006) Further Examination of The Link Between Work- Family Conflict and Physical Health: The Role of Health-Related Behaviors. American Behavioral Scientist, Vol.49, 1204-1221

Anand, Anjni. Vohra, Veena. (2019) A Qualitative Study on Work-Family Conflict, Social Support and Response Mechanisms of Individuals Working in Multi-National Corporations

Buzza, S. John. (2017) Are You Living to Work or Working to Live? What Millennials Want in the Workplace. Journal of Human Resources Management and Labor Studies, Vol. 5, No. 2, pp. $15-20$

Clark, C. Sue. (2000) Work / Family Border Theory: A New Theory of Work Family Balance. Journal of Human Relations, Vol. 53(6), pp. 747-770

Clark, C. Sue. (2001) Work Cultures and Work/Family Balance. Journal of Vocational Behavior $58,348-365$

Creswell, W. John. (2015) Penelitian Kualitatif dan Desain Riset: Memilih di Antara Lima Pendekatan. Edisi 3, ISBN: 978-602-229-358-3

Grady, Geraldine. McCarthy, M. Alma (2008) Work-Life Integration: Experiences of Mid-Career Professional Working Mothers. Journal of Managerial Psychology Vol. 23 No. 5, 2008 pp. 599-622

Grawitch, M. J., Barber, L. K., Justice, L. (2010) Rethinking The Work-Life Interface: It's Not About Balance, It's About Resource Allocation. Applied Psychology: Health and WellBeing, Vol. 2(2): 127-159

Greenhaus, H. Jeffrey, Beutell, J. Nicholas (1985) Sources of Conflict Between Work and Family Roles. Academy of Management Review, Vol.10, pp. 76-88

Greenhaus, H. Jeffrey. Collins, M. Karen. Shaw, D. Jason. (2002) The Relation Between WorkFamily Balance and Quality of Life. Journal of Vocational Behavior

Greenhaus, H. Jeffrey. Powell, N. Gary. (2003) When Work and Family Collide: Deciding Between Competing Role Demands. Journal of Organizational Behavior and Human Decision Processes, Vol. 90, pp. 291-303

Guest, D. E. (2002) Perspectives on the Study of Work-life Balance. Social Science Information Kirchmeyer, C. (2000) Work-Life Initiatives: Greed or Benevolence Regarding Workers Time

Kofodimos, R. Joan. (1993) Balancing Act: How Managers Can Integrate Successful Careers and Fulfilling Personal Lives. The Jossey-Bass Management Series. San Francisco, CA, US: Jossey-Bass 
Kossek, E., Lautsch, B. (2017) Work-Family Boundary Management Styles in Organizations: A Cross-Level Model. Organizational Psychology Review, Vol.2(2), 152-171

Levenson, R. Alec. (2010) Millennials and the World of Work: An Economist's Perspective. Journal of Business and Psychology, 25(2):257-264

Lyness, S.K., Judiesch, K.M. (2013) Gender Egalitarianism and Work-Life Balance for Managers: Multisource Perspectives in 36 Countries. Applied Psychology: An International Review, Vol. 63 (1), 96-129

Moen, P., Yu, Y. (2000) Effective Work/Life Strategies: Working Couples, Work Conditions, Gender, and Life Quality. Social Problems, Vol.47, 291-326

Moen, P., Kelly, E., \& Huang, R. (2008) Fit Inside The Work-Family Black Box: An Ecology of The Life Course, Cycles of Control Reframing. Journal of Occupational and Organizational Psychology, Vol. 81(3): 411-433

Moleong, J. Lexy. (2011) Metodologi Penelitian Kualitatif. Edisi Revisi Bandung

Moore, Fiona. (2007) Work-Life Balance: Contrasting Managers and Workers in an MNC. Employee Relations Vol. 29 No. 4, pp. 385-399

Muhr, L. Sara. Sullivan, R. Katie. (2013) None So Queer as Folk: Gendered Expectations and Transgressive Bodies in Leadership. Journal of Leadership, 9(3) 416-435

Myers, K. Karen. Sadaghiani, Kamyab. (2010) Millennials in the Workplace: A Communication Perspective on Millennials Organizational Relationships and Performance, Journal of Business and Psychology 25:225-238

Smith, T. Katherine. (2010) Work-Life Balance Perspectives of Marketing Professionals in Generation Y. Services Marketing Quarterly, Vol. 31 No. 4, pp. 434-447

Smith, A. Stephanie. (2018) Recruitment, Retention, and Engagement of a Millennial Workforce. ISBN: 978-1-4985-7970-4 (electronic)

Smola, W. Karen. Sutton, D. Charlotte (2002) Generational Differences: Revisiting Generational Work Values for The New Millennium. Journal of Organizational Behavior, Vol. 23, pp. 363-382

Sonier, D. (2012) Gen Xers and Millennials Still want Work-Life Balance. Healthcare Design, Vol. 12 No. 2, pp. 20-22

Spieler, I., Scheibe, S., \& Roßnagel, C. S. (2018) Keeping Work and Private Life Apart: Age Related Differences in Managing The Work-Nonwork Interface. Journal of Organizational Behavior, Vol.39, 1233-1251

Sulistyo, H. Organizational Citizenship Behavior of Islamic Banks Through Meaning in Life and Meaning of Work. (2017). Jurnal Keuangan dan Perbankan, Vol. 21(4): pp 589-600

Thomas, L. T., Ganster, D. C. (1995) Impact of Family-Supportive Work Variables on Work Family Conflict and Strain: A Control Perspective. Journal of Applied Psychology, 80(1), 615

Thompson, C.A., Beauvais, L.L., Lyness, K.S. (1999) When Work-Family Benefits are Not Enough: The Influence of Work-Family Culture on Benefit Utilization, Organizational Attachement, and Work-Family Conflict. Journal of Vocational Behavior, 54, 392-415

Thompson, Charles. Gregory, J. Brodie (2012) Managing Millennials: A Framework for Improving Attraction, Motivation, and Retention. The Psychologist-Manager Journal, Vol. 15, pp. 237246

Valcour, M. (2007) Work-Based Resources as Moderators of the Relationship Between Work Hours and Satisfaction with Work-Family Balance. Journal of Applied Psychology, Vol. 92 pp. 1512-1523

Vleira, J. M., Matias, M., Lopez, F. G., and Matos, P. M. (2016) "Relationships Between WorkFamily Dynamics and Parenting Experiences: A Dyadic Analysis of Dual-Earner Couples". Work and Stress, Vol. 30, pp. 243-261

Wayne, J.H. Musisca, N. Fleeson, W. (2004) Considering The Role of Personality in The WorkFamily Experience: Relationships of The Big Five to Work-Family Conflict and Facilitation. Journal of Vocational Behavior, Vol. 64, pp. 108-30. 